\title{
Analisa Pengaruh Return on Equity (ROE) Current Ratio (CR), Debt to Equity Ratio (DER), terhadap Dividend Payout Ratio (DPR)
}

(Studi Empiris Pada Perusahaan Manufaktur Yang Terdaftar Di Bursa Efek Indonesia Periode 2016-2020)

\author{
Misrofingah \\ Universitas Tama Jagakarsa \\ misrofingah66@gmail.com \\ Nurlelasari Ginting \\ Universitas Tama Jagakarsa \\ nurlelasariginting7@gmail.com
}

\begin{abstract}
Dividend Payout Ratio is the percentage of the amount of the dividend to be paid company's of total profits from the company to stockholders. The stockholders to invest they capital to get profits. For the company should be able to take a decision or a policy to pay dividends to stockholders or hold for reinvestment. This study aims to examine and analyze the effect of Return on Equity, Current Ratio, and Debt to Equity Ratio toward Dividend Payout Ratio in manufacture companies that listed in Indonesia Stock Exchange from 2016 to 2020. This research is quantitative research explanatory with data collection technique using a pruposive sampling. A total of 16 manufakturing firm are used as sample firm. Data analysis method used is multiple linear regression analysis. The test data used is normality test, test (t), test (f), and the coefficient of determination. The results of this research are: ROE positive effect on DPR, CR no effect on DPR, DER negative effect on $D P R$.
\end{abstract}

Keywords Return on Equity (ROE), Current Ratio (CR), Debt to Equity Ratio (DER), Dividend Payout Ratio (DPR).

\section{PENDAHULUAN}

Kemajuan dunia perekonomian saat ini, menuntut perusahaan untuk memiliki dana yang lebih besar dari pada sebelumnya, agar perusahaan juga ikut berkembang bersama dengan pertumbuhan ekonomi global. Untuk mendapatkan dana yang besar salah satu pilihan perusahaan adalah dengan mencari investor untuk perusahaannya.

Pada umumnya, tujuan utama seorang investor dalam menanamkan dananya ke dalam perusahaan adalah untuk memperoleh laba atau tingkat pengembalian investasi, baik berupa pendapatan dari selisil harga jual saham terhadap harga belinya (capital again) maupun dari pendapatan dividen (dividend yield). Investor selalu berharap untuk mendapatkan dividen dalam jumlah yang besar atau minimal relatif stabil dari tahun ke tahun. Dividen adalah sebagian dari laba bersih yang dibagikan kepada investor, dan sebagian lain dari laba bersih perusahaan merupakan laba ditahan yang dijadikan perusahaan sebagai dana cadangan, yang biasanya digunakan untuk investasi kembali.

Bagi perusahaan, kebijakan dalam penentuan besarnya presentase yang akan dibagikan sebagai dividen (Dividend Payout Ratio) sangatkah penting, karena setiap 
keputusan yang diambil manajemen perusahaan dalam kebijakan pembayaran dividen akan membawa dua dampak yang saling bertolak belakang. Di satu sisi, setiap perusahaan selalu menginginkan adanya pertumbuhan terhadap perusahaan tersebut, dengan semakin banyaknya dana cadangan yang dimilikinya, karena perusahaan akan leluasa untuk melakukan investasi-investasi lain. Di sisi lain, manajemen perusahaan juga harus memikirkan kesejahteraan para investornya dengan membagikan dividen yang sesuai, karena pendapatan dividen yang besar akan menjadi motivasi bagi para investor untuk terus menanamkan modalnya dan kepercayaan investor terhadap perusahaan juga semakin tinggi, itu semua secara tidak langsung bisa mempengaruhi harga saham. Dengan demikian, dapat dikatakan bahwa semakin tingginya Dividend Payout Ratio (DPR) yang dibagikan akan semakin kecil pendapatan yang ditahan dalam perusahaan, dan sebaliknya semakin besar pendapatan yang ditahan untuk perusahaan akan semakin kecil dividen yang dibagikan.

Pertimbangan mengenai penentuan Dividend Payout Ratio (DPR) sangat berkaitan dengan kinerja keuangan perusahaan. Bila kinerja keuangan perusahaan bagus maka perusahaan tersebut akan mampu menetapkan besarnya Dividend Payout Ratio (DPR) sesuai dengan harapan pemegang saham tanpa harus mengabaikan kepentingan perusahaan untuk tetap tumbuh.

Investor harus memilih perusahaan mana yang mempunyai potensi untuk bisa memberikan dividen yang besar, dengan cara mengamati dan menganalisis informasiinformasi tentang perusahaan, masalah-masalah yang sedang dihadapi, dan terutama tentang kinerja keuangan perusahaan, yang bisa didapatkan dari annual report tahunan yang telah dipublikasikan. Cara investor untuk menganalisis laporan keuangan perusahaan dengan menggunakan rasio keuangan.

Rasio keuangan adalah angka yang diperoleh dari hasil perbandingan dari satu pos laporan keuangan dengan pos lainnya yang mempunyai hubungan yang relevan dan signifikan. Rasio keuangan ini hanya menyederhanakan informasi yang menggambarkan hubungan antar pos-pos tertentu. Sehingga kita bisa menilai secara tepat hubungan antar pos dan bisa membandingkan dengan rasio lain (Hadiwidjaja, 2007).

Faktor-faktor penentu yang diteliti dalam penelitian ini adalah Dividend Payout Ratio (DPR) sebagai variabel terikat, sedangkan variabel bebasnya adalah profitabilitas, likuiditas, dan Laverage yang dinyatakan dalam rasio keuangan. Profitabilitas menggunakan Rasio Laba atas Modal (Return On Equity), Likuiditas menggunakan Rasio Lancar (Current Rasio), sedangkan Laverage menggunakan Rasio Kewajiban Jangka Panjang atas Modal (Debt to Equity Ratio).

Perusahaan manufaktur adalah perusahaan yang menjual produknya dimulai dari proses produksi yang berkelanjutan, dari pembelian bahan baku dilanjutkan dengan pengolahan bahan baku sampai menjadi produk yang siap jual dilakukan sendiri oleh perusahaan tersebut sehingga banyak dana yang tersedia akan lama terikat pada aktiva tetap. Maka dari itu, perusahaan manufaktur lebih membutuhkan sumber dana jangka panjang untuk membiayai operasi perusahaan mereka salah satunya dengan investasi saham, tentunya itu semua berhubungan dengan deviden. Maka dari itu, peneliti mengambil sektor manufaktur sebagai obyek pada penelitian ini.

\section{LANDASAN TEORI}

\section{Teori Keagenan (Agency Theory)}

Puspitasari dan Darsono (2020) menyatakan kebijakan dividen tidak dapat dipisahkan dengan teori keagenan. Dalam teori keagenan (agency theory) yang 
menjelaskan hubungan yang timbul karena adanya kontrak antara pemegang saham (prinsipal) yang mendelegasikan tanggung jawab pengelolaan perusahaan kepada manajemen (agen). Asumsi yang digunakan dalam agency theory adalah bahwa masingmasing individu (prinsipal dan agen) termotivasi untuk memperoleh kepuasan dirinya sendiri. Manajer cenderung mengambil keputusan untuk menginvestasikan kembali keuntungan yang diperolehnya dengan tujuan agar perusahaan mengalami pertumbuhan tinggi. Kepentingan ini seringkali tidak sejalan dengan keinginan pemegang saham yang menginginkan keuntungan dibagi dalam bentuk dividen, sehingga dapat menyebabkan konflik antara pemegang saham dan manajer.

\section{Dividen}

Menurut Martani (2015:106) dividen adalah bagian laba yang didistribusikan kepada pemengang saham. Perusahaan mengeluarkan dividen berdasarkan keputusan yang diambil dalam Rapat Umum Pemegang saham (RUPS).

Kebijakan dividen (dividend policy) adalah seluruh keputusan manajerial yang dilakukan untuk menetapkan berapa besar laba bersih yang dibagikan kepada pemegang saham dan berapa besar laba bersih yang tetap ditahan untuk cadangan investasi tahun depan. Kebijakan itu akan tercermin dari besarnya perbandingan laba yang dibayarkan sebagai dividen terhadap laba bersih (Mardiyanto,2008:4)

\section{Divident Payout Ratio (DPR)}

Cash dividend merupakan bagian laba yang dibagikan kepada pemegang saham, sedangkan presentase dari laba yang akan dibagikan sebagai cash dividend disebut sebagai Divident Payout Ratio (DPR). Semakin tinggi Divident Payout Ratio (DPR), maka semakin kecil porsi dana yang tersedia untuk ditanamkan kembali ke perusahaan sebagai laba ditahan (Rahmawati:2008).

Menurut Miswandi dan Julita (2020), rumus dalam perhitungan Divident Payout Ratio (DPR) adalah Divident Payout Ratio $(\mathrm{DPR})=$ Dividen yang Dibayarkan /Laba Bersih

\section{Return on Equity (ROE)}

Menurut Sugiono (2009:81) rasio ini mengukur tingkat pengembalian dari bisnis atas modal yang ada. ROE merupakan salah satu indikator yang digunakan oleh pemegang saham untuk mengukur keberhasilan bisnis yang dijalani. Menurut Kasmir (2020:135), rumus dalam perhitungan current ratio adalah

Return on Equity $(\mathrm{ROE})=$ Earning After Interst and Tax / Equity

\section{Current Ratio (CR)}

Menurut Kasmir (2020:134) rasio lancar atau current ratio merupakan rasio untuk mengukur kemampuan perusahaan dalam membayar kewajiban jangka pendek atau utang yang segera jatuh tempo pada saat ditagih secara keseluruhan. Dengan kata lain, seberapa banyak aktiva lancar yang tersedia untuk menutupi kewajiban jangka pendek yang segera jatuh tempo. Makin tinggi jumlah aktiva lancar (relatif terhadap utang lancar) makin tinggi rasio lancar, yang berarti pula makin tinggi tingkat likuiditas perusahaan (Mardianto, 2008:55). Perhitungan rasio lancar dilakukan dengan cara membandingkan antara total aktiva lancar dengan total utang lancar Menurut Kasmir (2020:135), rumus dalam perhitungan current ratio adalah Current ratio $=$ Aktiva Lancar $/$ Utang Lancar 


\section{Debt to Equity Ratio (DER)}

Menurut Syamsuddin (2017:54) Debt to equity ratio merupakan rasio yang menunjukkan hubungan antar jumlah pinjaman jangka panjang yang diberikan oleh para kreditur dengan jumlah modal sendiri yang diberikan pemilik perusahaan. Apabila suatu perusahaan menentukan bahwa pelunasan utangnya akan diambilkan dari laba ditahan, berarti perusahaan harus menahan sebagian besar dari pendapatannya untuk keperluan tersebut, hal ini berarti hanya sebagian kecil saja yang pendapatan yang dapat dibayarkan sebagai dividen (Samrotun:2015). Menurut Kasmir (2020:158), rumus dalam perhitungan Debt to equity ratio adalah

Debt to equity ratio $=$ Total Utang/ Ekuitas

\section{Penelitian Terdahulu}

Penelitian tentang dividen juga dilakukan oleh Ni Luh Ayu Wahyuni (2015) dengan judul "Pengaruh Profitabilitas Dan Likuiditas Terhadap Besarnya Dividen Yang Dibagikan Kepada Pemegang Saham Pada Perusahaan Manufaktur yang Terdapat Di BEI Periode 2016-2020". Teknik sampling yang digunakan adalah purposive sampling sehingga mendapatkan sampel berjumlah 14 perusahaan. Hasil pada penelitian ini adalah baik secara parsial maupun simultan profitabilitas dan likuiditas berpengaruh terhadap besarnya dividen.

Novia Ayu Puspita dan Darsono (2020) juga meneliti tentang dividen, dengan judul "Faktor-faktor yang Berpengaruh Terhadap Kebijakan Dividen" pada perusahaan yang manufaktur yang terdaftar di BEI selama periode 2009-2017. Teknik sampling yang digunakan adalah purposive sampling sehingga mendapatkan sampel berjumlah 188 perusahaan. Hasil pada penelitian ini adalah bahwa leverage dan profitabilitas yang berpengaruh terhadap kebijakan dividen. Leverage berpengaruh negatif terhadap kebijakan dividen, sedangkan profitabilitas berpengaruh positif terhadap kebijakan dividen.

Tita Deitana juga (2009) juga meneliti tentang dividen dengan judul " Faktorfaktor yang Mempengaruhi Kebijakan Pembayaran Dividen Kas" pada perusahaan manufaktur dan non manufaktur selain bank dan lembaga keuangan lainnya yang terdaftar di Bursa Efek Jakarta tahun 2003-2007. Teknik sampling yang digunakan adalah purposive sampling sehingga mendapatkan sampel berjumlah 21 perusahaan. terdapat pengaruh signifikan antara Earning per Share dan Price Earning Ratio terhadap Dividend Payout Ratio. Sedangkan tidak ada pengaruh signifikan antara Debt to Equity Ratio, Return on Asset, Current Ratio, Net Profit Margin, Inventory Turnover, dan Return on Equity terhadap Dividend Payout Ratio.

\section{METODOLOGI PENELITIAN Pendekatan Penelitian}

Penelitian ini menggunakan penelitian kuantitatif eksplanatoris yang menjelaskan hubungan antara variabel-variabel penelitian melalui pengujian hipotesis.

\section{Populasi dan Teknik Pengambilan Sampel}

Dalam penelitian ini populasi yang digunakan adalah perusahaan manufaktur yang telah go public dan terdaftar pada Bursa Efek Indonesia pada periode 2016 hingga 2020 sebanyak 126 perusahaan manufaktur. Teknik Pengambilan Sampel dalam penelitian ini menggunakan purposive Sampling. 
Sampel perusahaan yang dipilih didasarkan pada kriteria tertentu. Beberapa kriteria tersebut antara lain: (a) Perusahaan manufaktur yang selalu terdaftar dan go public di BEI dari tahun 2016-2020. (b) Perusahaan manufaktur yang menerbitkan laporan keuangan dari tahun 2016-2020. (c) Perusahaan manufaktur yang selalu membagikan dividen dan dividend payout ratio stabil dari tahun 2016-2020.

Berdasarkan kriteria teknik sampling diatas maka jumlah sampel yang digunakan dalam penelitian ini adalah 16 perusahaan manufaktur yang terdaftar di Bursa Efek Indonesia tahun 2016-2020.

\section{Metode Pengumpulan Data}

Dalam penelitian ini data yang digunakan adalah data sekunder yaitu berasal dari situs resmi Bursa Efek Indonesia (www.idx.co.id). Data bersumber dari internal perusahaan yaitu berupa laporan keuangan perusahaan dan profil perusahaan selama tahun 2016-2020. Data yang digunakan merupakan gabungan data antarperusahaan (cros section) dan antarwaktu (time series) atau disebut dengan polling.

Instrumen penelitian yang digunakan dalam penelitian ini adalah dokumentasi dengan cara melihat, mempelajari, dan mengutip catatan-catatan yang diperoleh dari dokumen Bursa Efek Indonesia berupa laporan keuangan perusahaan, laporan tahunan dan laporan profile perusahaan periode tahun 2016-2020 dan dengan penelitian pustaka

\section{Definisi Operasional dan Pengukuran Variabel Dividend Payout Ratio (DPR)}

Dividend Payout Ratio dalam penelitian ini sebagai variabel terikatnya. Dividend Payout Ratio atau rasio pembayaran dividen adalah perbandingan antara dividen yang dibayarkan dengan laba bersih yang didapatkan perusahaan Manufaktur yang terdaftar di BEI periode 2016 sampai 2020, dan biasanya disajikan dalam bentuk persentase.

Divident Payout Ratio $(\mathrm{DPR})=$ Dividen yang Dibayarkan / Laba Bersih

\section{Return On Equity (ROE)}

Return On Equity (ROE) untuk mengukur seberapa besar pengembalian yang diperoleh pemilik bisnis(pemegang saham) atas modal yang disetorkan untuk bisnis tersebut, dan dihitung dengan cara membagi laba bersih dengan total ekuitas pada perusahaan Manufaktur yang terdaftar di BEI periode 2016 sampai 2020. Semakin besar rasio ini maka semakin baik kemampuan perusahaan untuk menghasilkan keuntungan dari modalnya sendiri.

Return on Equity $(\mathrm{ROE})=$ Laba Bersih / Total ekuitas

\section{Current Ratio (CR)}

Current Ratio (CR) adalah untuk mengukur seberapa jauh aktiva lancar perusahaan bisa dipakai untuk memenuhi kewajiban lancarnya, dan dihitung dengan cara membagi aktiva lancar dengan kewajiban lancar pada perusahaan Manufaktur yang terdaftar di BEI periode 2016 sampai 2020. Semakin tinggi current ratio menunjukkan kemampuan perusahaan dalam memenuhi kewajiban jangka pendeknya (termasuk di dalamnya membayar dividen yang terhutang).

Current ratio $=$ Aktiva Lancar $/$ Utang Lancar

\section{Debt to Equity Ratio (DER)}

Debt to Equity Ratio (DER) membandingkan antara hutang yang dimiliki perusahaan dengan modal sendiri pada perusahaan Manufaktur yang terdaftar di BEI periode 2016 sampai 2020. Semakin tinggi rasio ini berarti modal sendiri semakin sedikit 
dibanding dengan hutangnya. Bagi perusahaan sebaiknya besarnya hutang tidak boleh melebihi modal sendiri agar beban tetapnya tidak terlalu tinggi. Jika beban hutang semakin tinggi maka kemampuan perusahaan untuk membagi dividen akan semakin rendah.

$$
\text { Debt to equity ratio }=\text { Total Utang } / \text { Ekuitas }
$$

\section{Metode Analisis Data \\ Statistik Deskriptif}

Menurut Sugiyono (2020:147) statistik deskriptif adalah statistik yang digunakan untuk menganalisis data dengan cara mendeskripsikan atau menggambarkan data yang telah terkumpul sebagaimana adanya tanpa bermaksud membuat kesimpulan yang berlaku untuk umum atau generalisasi.

\section{Uji Normalitas}

Uji normalitas bertujuan untuk menguji apakah dalam model regresi, variabel pengganggu atau residual memiliki distribusi normal. Uji Normalitas ini dengan menggunakan P-Plot dan One-Sample Kolmogorov-Smirnov. Pedoman dalam mengambil keputusan apakah sebuah distribusi data mengikuti distribusi normal adalah jika nilai sig. lebih besar dari 5\% maka distribusi adalah normal dan sebaliknya.

\section{Analisis Regresi Linear Berganda}

Berdasarkan pola hubungan antar variabel dalam penelitian ini, metode pengolahan data dalam penelitian ini menggunakan metode regresi linear berganda. Alasan menggunakan motode linear berganda dikarenakan untuk melihat pengaruh langsung dari variabel dependen dan variabel independen. Persamaan yang digunakan dalam regresi linear berganda ini adalah sebagai berikut :

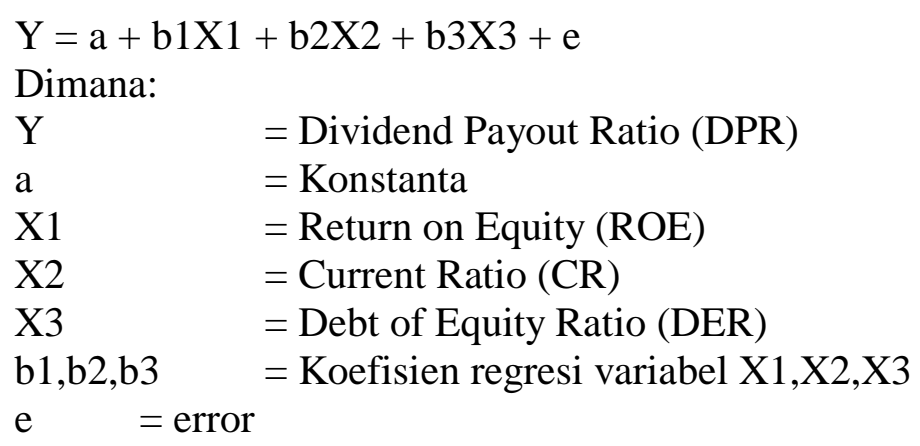

\section{Koefisien Determinasi (R2)}

Koefisien determinasi adalah untuk mengetahui seberapa besar variasi variabel independen dapat menjelaskan variabel dependen (Marlina dan Danica, 2009). Nilai R2 berkisar antara nol sampai satu, semakin mendekati angka satu dapat dikatakan model tersebut semakin baik model regresi yang digunakan karena menandakan bahwa kemampuan variabel bebas menjelaskan variabel terikat juga semakin besar.

\section{Uji Pengaruh Parsial (Uji-t)}

Marlina dan Danisa (2009) pengujian ini dilakukan untuk menguji apakah setiap variabel bebas mempunyai pengaruh yang signifikan terhadap variabel terikat. Bentuk pengujian:

H0 : $b 1=b 2=b 3=0$, artinya tidak terdapat pengaruh yang signifikan dari variabel besas secara individual terhadap variabel terikat 
$\mathrm{H}(1,2,3): \mathrm{b} 1 \neq \mathrm{b} 2 \neq \mathrm{b} 3 \neq 0$, artinya terdapat pengaruh yang signifikan dari variabel besas secara individual terhadap variabel terikat

Pada penelitian ini nilai t hitung akan dibandingkan dengan $t$ tabel pada tingkat signifikan $(\alpha)=5 \%$. Kriteria pengambilan keputusan pada uji-t ini adalah:

$\mathrm{H} 0$ diterima jika : $\mathrm{t}$ hitung $\leq \mathrm{t}$ tabel

$\mathrm{H}(1,2,3)$ diterima jika : $\mathrm{t}$ hitung $>\mathrm{t}$ table

\section{Uji Pengaruh Serempak (Uji-F)}

Marlina dan Danisa (2009) menyatakan pengujian ini dilakukan untuk mengetahui apakah variabel bebas secara serempak mempunyai pengaruh yang signifikan terhadap variabel terikat. Bentuk pengujian:

$\mathrm{H} 0: \mathrm{b} 1=\mathrm{b} 2=\mathrm{b} 3=0$, artinya variabel bebas secara serempak tidak mempunyai pengaruh yang signifikan terhadap variabel terikat.

$\mathrm{H}(4): \mathrm{b} 1 \neq \mathrm{b} 2 \neq \mathrm{b} 3 \neq 0$, artinya variabel bebas secara serempak berpengaruh signifikan terhadap variabel terikat.

Pada penelitian ini nilai Fhitung akan dibandingkan dengan Ftabel pada tingkat signifikan $(\alpha)=5 \%$. Kriteria penilaian hipotesis pada uji-F ini adalah:

Terima $\mathrm{H} 0$ bila $\mathrm{F}$ hitung $\leq \mathrm{F}$ tabel

Tolak H0 (terima H4) bila F hitung > F tabel

\section{HASIL PENELITIAN}

\section{Pengaruh Return on Equity (ROE) terhadap Dividend Payout Ratio (DPR)}

Dari hasil pengujian, diketahui bahwa variabel Return on Equity (ROE) berpengaruh positif dan signifikan terhadap Dividend Payout Ratio (DPR). Hasil ini sesuai dengan teori yang diungkapkan oleh Sudana (2017 : 22) bahwa semakin tinggi Return on Equity ( $R O E$ ) maka semakin efisien penggunaan modal sendiri yang dilakukan oleh pihak manajemen perusahaan. Hal ini berarti bahwa semakin besar nilai Return on Equity (ROE) sebagai rasio profitabilitas perusahaan maka semakin besar pula Dividend Payout Ratio (DPR). Hal ini mengindikasikan bahwa tinggi rendahnya profitabilitas perusahaan akan membawa dampak mengenai ketertarikan minat investor dalam menanamkan modalnya dengan harapan mendapatkan keuntungan yang tinggi dari pembagian dividen.

Hasil penelitian ini sejalan dengan penelitian yang dilakukan oleh Ni Luh Ayu Wahyuni (2015) yang menyatakan bahwa Return on Equity (ROE) berpengaruh positif dan signifikan terhadap Dividend Payout Ratio (DPR). Dalam penelitiannya Ni Luh Ayu Wahyuni (2015) juga menyatakan bahwa rasio profitabilitas ini lebih diminati oleh para pemegang saham dan manajemen perusahaan sebagai salah satu alat keputusan investasi.

\section{Pengaruh Current Ratio (CR) terhadap Dividend Payout Ratio (DPR)}

Hasil pengujian menunjukkan bahwa variabel Current Ratio (CR) tidak berpengaruh terhadap Dividend Payout Ratio (DPR). Hasil ini tidak sesuai dengan teori yang dikemukakan oleh Mardianto (2008:55) bahwa makin tinggi jumlah aktiva lancar (relatif terhadap utang lancar) makin tinggi rasio lancar, yang berarti pula makin tinggi tingkat likuiditas perusahaan. Hal ini berarti bahwa semakin besar nilai Curent Ratio $(C R)$ sebagai rasio likuiditas perusahaan maka semakin besar pula Dividend Payout Ratio $(D P R)$ yang dibayarkan. Namun, hasil ini sesuai dengan penelitian terdahulu yang dilakukan oleh Tita Deitiana (2009) yang mana Current Ratio (CR) tidak perpengaruh terhadap dividen kas. Menurut penelitian Tita, hasil ini mengindikasikan bahwa Current 
Rasio tidak dipertimbangkan oleh manajemen dalam pembayaran dividen kas, tetapi dialokasikan pada pembelian aktiva tetap atau aktiva lancar yang permanen guna memanfaatkan kesempatan investasi yang ada,serta untuk biaya operasional.

\section{Pengaruh Debt to Equity Ratio (DER) terhadap Dividend Payout Ratio (DPR)}

Dari hasil pengujian, diketahui bahwa variabel Debt to Equity Ratio berpengaruh negatif dan signifikan terhadap Dividend Payout Ratio. Hasil ini sesuai dengan teori yang dikemukakan oleh Sudana (2017:21) yang menyatakan bahwa semakin besar Debt to Equity Ratio, mencerminkan resiko keuangan perusahaan yang semakin besar. Modal sendiri semakin sedikit dibandingkan dengan hutangnya. Hal ini berarti jika Debt to Equity Ratio semakin rendah, maka kemampuan perusahaan untuk membagi dividen akan semakin meningkat,sehingga akan memberikan sinyal informasi yang positif tentang dividen. Hasil ini juga didukung oleh penelitian Miswandi dan Julita (2020) dan Puspitasari dan Darsono (2020) yang mana hasil penelitiannya menunjukkan bahwa Debt to Equity Ratio secara parsial memiliki hubungan yang negatif dan signifikan terhadap Dividend Payout Ratio. Puspitasari dan Darsono (2020) juga menyatakan dalam penelitiannya bahwa penggunaan hutang sebagai sumber pendanaan akan menyebabkan perusahaan harus menanggung cicilan hutang dan bunga. Hal ini dikarenakan pembayaran cicilan hutang dan bunga lebih diprioritaskan dari pada membagikan dividen, sehingga semakin tinggi Debt To Equity Ratio (DPR) maka semakin rendah dividen yang dibagikan.

\section{KESIMPULAN}

Variabel Return on Equity (ROE) berpengaruh positif terhadap Dividend Payout Ratio (DPR) terbukti. Hasil pengujian ini mendukung $\mathrm{H}_{1}$ bahwa Return on Equity (ROE) berpengaruh terhadap Dividend Payout Ratio (DPR). Hal ini mengidentifikasikan bahwa tinggi rendahnya profitabilitas perusahaan akan membawa dampak mengenai ketertarikan minat investor dalam menanamkan modalnya dengan harapan mendapatkan keuntungan yang tinggi dari pembagian dividen.

Variabel Current Ratio (CR) tidak berpengaruh terhadap Dividend Payout Ratio $(D P R)$. Dengan kata lain, hasil ini tidal mendukung $\mathrm{H}_{2}$ yang menyatakan bahwa variabel Current Ratio berpengaruh terhadap Dividend Payout Ratio. Adanya tingkat likuiditas oleh perusahaan tidak digunakan untuk membayar dividen tetapi dialokasikan pada pembelian aktiva tetap atau aktiva lancar yang permanen guna memanfaatkan kesempatan investasi yang ada serta digunakan untuk biaya operasional.

Variabel Debt to Equity Ratio (DER) berpengaruh negatif terhadap Dividend Payout Ratio (DPR) terbukti. Hasil pengujian ini mendukung $\mathrm{H}_{3}$ bahwa Debt to Equity Ratio (DER) berpengaruh terhadap Dividend Payout Ratio. Hal ini berarti dapat disimpulkan bahwa Debt to Equity Ratio (DER) dalam penelitian ini merupakan sinyal positif bagi para investor mengenai dividen yang akan diterima.

Variabel Return on Equity (ROE), Current Ratio (CR) dan Debt to Equity Ratio $(D E R)$ dalam penelitian ini terbukti secara simultan berpengaruh terhadap Dividend Payout Ratio $(D P R)$. Hasil pengujian ini mendukung $\mathrm{H}_{4}$ yang menyatakan bahwa terdapat pengaruh Return on Equity (ROE), Current Ratio (CR) dan Debt to Equity Ratio (DER) secara simultan terhadap terhadap Dividend Payout Ratio (DPR). 


\section{DAFTAR PUSTAKA}

Hadiwidjaja, R. D. (2007). "Analisis Faktor-Faktor yang Mempengaruhi Dividend Payout Ratio pada Perusahaan Manufaktur di Indonesia". Tesis, Sekolah Pascasarjana Universitas Sumater Utara Medan

Martani, Dwi, dkk. (2015). "Akuntansi Keuangan Menengah Berbasis PSAK". Jakarta:Salemba Empat

Mardiyanto, Handono. (2008). Inti Sari Manajemen Keuangan. Jakarta : PT. Grasindo.

Puspitasari, N. A, dan Darsono. (2020). "Faktor-Faktor yang Berpengaruh terhadap Kebijakan Dividen". Journal Of Accounting, Vol.3, No.2, Hal.1, ISSN.23373806

Rahmawati, S. N. (2008). "Faktor-Faktor yang Mempengaruhi Dividend Payout Ratio (Studi Empiris pada Perusahaan yang Terdaftar di Jakarta Islamic Index periode 2000-2004)". Skripsi, Universitas Islam Negeri Sunan Kalijaga

Miswandi, Nur, E, dan Julita. (2020). "Analisis Faktor-Faktor yang Mempengaruhi Dividend Payout Rasio (DPR) pada Perusahaan yang Terdaftar di BEI". Jom Fekon, vol.1, No.2, Oktober

Sugiono, Arif. (2009). Manajemen Keuangan untuk Praktisi Keuangan. Jakarta: PT. Grasindo.

Kasmir. (2020). Analisis Laporan Keuangan. Jakarta : PT Rajagrafindo Persada

Wahyuni, N. L. A. (2015). "Pengaruh Profitabilitas Dan Likuiditas Terhadapbesarnya Dividen Yang Dibagikan Kepada Pemegang saham Pada Perusahaan Manufakturyang Terdapat Di BEI". Jurnal Akuntansi, Vol.5, No.1

Syamsuddin, Lukman (2017). Manajemen Keuangan Perusahaan . Konsep Aplikasi dalam: Perencanaan, Pengawasan, dan Pengambilan Keputusan. Jakarta: Rajawali Pers

Samrotun, Y. C. (2015). "Kebijakan Dividen dan Faktor-Faktor yang Mempengaruhinya". Jurnal Paradigma, Vol.13, No.01, ISSN.1693-0827

Deitiana, T. (2009). "Faktor-Faktor yang Mempengaruhi Kebijakan Pembayaran Dividen Kas". Jurnal Bisnis dan Akuntansi, Vol.11, No.1, 57-64

Sugiyono. (2020). Metode Penelitian Kuantitatif, Kualitatif dan R \& D. Cetakan ke 20. Bandung: Alfabeta.

Marlina, L, dan Danica, C. (2009). “Analisis Pengaruh Cash Position, Debt to Equity Ratio, dan Return on Assets terhadap Dividend Payout Ratio". Jurnal Manajemen Bisnis, Vol.2, No.1, 1-6

Rahmawati, S. N. (2008). "Faktor-Faktor yang Mempengaruhi Dividend Payout Ratio (Studi Empiris pada Perusahaan yang Terdaftar di Jakarta Islamic Index periode 2000-2004)”. Skripsi, Universitas Islam Negeri Sunan Kalijaga 